\title{
STRAFFRÄTTENS FÖRUTSÄTTNINGAR OCH BEGRÄNSNINGAR SOM STYRMEDEL AV MILJÖSKADLIG VERKSAMHET
}

\author{
AV PROFESSOR PER Ole TräSKMAN
}

This article deals with the necessary prerequisites, potential benefits, and existing limitations surrounding the use of the criminal code in contributing to a healthy environment and a sustainable development.

Environmental legislation has been given significantly greater emphasis within the penal codes of the Nordic countries during the past few decades. This is reflected in both the expansion of the codes to include a greater number of environmental offences, as well as an increase in the maximum penalties available for existing offences. In order to streamline the implementation of these changes, the focus of traditional crime control agencies has been broadened to include them. Sweden, for example, has reinforced its police departments and developed an environmental prosecution unit consisting of 20 public prosecutors specialised in environmental legislation. Such changes answer the demand for a more efficient environmental policy, a more efficient environmental law, and a more efficient environmental penal legislation.

Politicians have suggested that the fight against environmental offences should be a prioritised part of the traditional fight against crime. Political proposals have demanded a specific environmental criminal policy that is both more efficient and better integrated into existing law enforcement.

Does this imply that a specific program for environmental criminal policy - based on a core of the existing environmental criminal legislation already exists, or rather that such a program is going to be drawn up? Are environmental issues going to be a part of the general criminal and penal political program? This is certainly implied since it seems unreasonable to exclude an area that has been characterised as a prioritised part of crime control policy. Nonetheless, environmental penal legislation can never be totally disconnected from environmental law. In the end, environmental penal legislation is merely a tool for the efficient implementation of environmental law. The consequences of treating environmental legislation as an issue for both environmental law and criminal law entails certain problems and contradictions are analysed in this article.*

\section{En uppstramning av miljöstraffrätten}

En god miljö har en fundamental betydelse för allt liv.

Detta är en grundsats som erkänns allmänt, samtidigt som behovet av att på

* Title in English: Prerequisites and Limitations for using the Criminal Code to Address Environmentally Damaging Activities. Original in Swedish. 
allt sätt skydda och bevara miljön betonas. I den preambel som ingår i den europeiska konventionen om skyddet av miljön genom straffrättsliga medel, sluten den 4 november 1998, fastslås att människornas liv och hälsa, miljötillgångarna samt floran och faunan måste skyddas med alla tillbudsstående medel. Då det gäller förebyggandet av miljöskador och återställandet av redan skadad miljö är det framför allt andra medel än de straffrättsliga som kan användas, men när det gäller skyddet av miljön har straffrätten en vigtig roll. Miljöskadorna har allvarliga konsekvenser och därför måste man definiera de relevanta gärningarna som brott och utsätta lämpliga straff för dem. Det skall säkerställas att de som ansvarar för sådana brott inte undgår ansvar.'

Syftet med denna artikel är att se på straffrättens förutsättningar och begränsningar då det gäller att bidra till en god miljö och en bärkraftig utveckling. Den vinkel som har valts är primärt straffrättslig: miljöstraffrätten granskas först och främst som straffrätt och inte som miljörätt. Genom denna vinkling vill jag få fram sådana motsättningar som inte har beaktats tillräckligt, då den straffrättsliga kontrollen på miljöområdet förstärkts.

Miljöstraffrätten har genomgått en markant förstärkning i Norden under de senaste decennierna. De förstärkande åtgärderna har varit medvetna och i stor utsträckning grundade på en mycket enhetlig uppfattning om att den straffrättsliga kontrollen av miljöfarlig och miljöskadlig verksamhet är förenad med stora problem, och att dessa problem under lång tid i själva verket medförde att den straffrättsliga kontrollen på miljöområdet var tämligen betydelselös. ${ }^{2}$ Denna förstärkning av miljöstraffrätten har bl.a. inneburit att man i vissa av de nordiska länderna har intagit nya straffbestämmelser gällande miljöbrott i strafflagen. Här kan särskilt Finland nämnas. I samband med den totala revideringen av den finska strafflagen infogades ett nytt kapitel (48 kap.) i strafflagen med rubriken "Om miljöbrott".

I Sverige genomfördes den reform som avsåg att förstärka det rättsliga miljöskyddet genom utarbetandet av en ny miljöbalk. I denna nya miljöbalk intogs också de relevanta straffbestämmelserna, varvid de tidigare bestämmelserna om miljöbrott i brottsbalkens 13 kapitel upphävdes.

\section{Straffbestämmelserna i 1999 års miljöbalk - straffrätt eller miljörätt?}

De åtgärder som vidtogs i Sverige vid införandet av miljöbalken år 1999 (lag 1998:808). Kännetecknades av intentioner med ett brett miljöperspektiv. Vad man ville åstadkomma var en ny samordnad, skärpt och breddad lagstiftning mot en hållbar utveckling. Alla centrala regler till skydd för människors hälsa och miljön, för värdefulla natur- och kulturmiljöer och för den biologiska mångfalden samlades i en enda lag.

Målet med denna sammanhållna, enhetliga lagstiftning är att främja en hållbar utveckling. ${ }^{3}$ Detta framgår klart av lagens första paragraf, som anger lagstiftningens överordnade mål: 
"Bestämmelserna i denna balk syftar till att främja en hållbar utveckling som innebär att nuvarande och kommande generationer tillförsäkras en hälsosam och god miljö. En sådan utveckling bygger på insikten att naturen har ett skyddsvärde och att människans rätt att förändra och bruka naturen är förenad med ett ansvar för att förvalta naturen väl.

Miljöbalken skall tillämpas så att

1. människors hälsa och miljön skyddas mot skador och olägenheter oavsett om dessa orsakas av föroreningar eller annan påverkan,

2. värdefulla natur- och kulturmiljöer skyddas och vårdas,

3. den biologiska mångfalden bevaras,

4. mark, vatten och fysisk miljö i övrigt används så att en från ekologisk, social, kulturell och samhällsekonomisk synpunkt långsiktigt god hus hållning tryggas, och

5. återanvändning och återvinning liksom annan hushållning med material, råvaror och energi främjas så att ett kretslopp uppnås."

Den miljöpolitik som utstakas här innebär att alla som bedriver eller avser att bedriva en verksamhet eller vidta en åtgärd (som inte är av försumbar betydelse i det enskilda fallet) är skyldig att iaktta vissa förpliktelser. Man skall skaffa sig den kunskap som behövs, man skall iaktta försiktighetsprincipen, man skall hushålla med råvaror och energi samt utnyttja möjligheter till återanvändning och återvinning. Man skall iaktta produktvalsprincipen och välja sådana produkter och organismer som kan antas vara de minst farliga. I många fall föreligger en tillståndsplikt.

Allting skall förenas med en effektiv kontroll. I organisatoriskt avseende har tillsynsmyndigheterna förstärkts, varvid man starkt har framhävt att de skall samarbeta med varandra samt med sådana statliga och kommunala organ som skall utöva tillsyn i särskilda hänseenden eller som på annat sätt fullgör uppgifter av betydelse för tillsynsverksamheten. Vad som förutsätts är en effektiv bekämpning av överträdelser. Då det gäller brott har tillsynsmyndigheterna pålagts en absolut anmälningsplikt: de skall anmäla överträdelser av bestämmelser i miljöbalken, eller i föreskrifter som har meddelats med stöd av balken, till polis- eller åklagarmyndigheten så snart det finns misstanke om brott (miljöbalken 26 kap. 2 §). Samtidigt har de traditionella brottskontrollerande myndigheternas beredskap att handlägga miljöbrott förbättrats. Polismyndigheterna har fått förstärkningar, och inom åklagarorganisationen har man bl.a. inrättat en särskild miljöbrottsenhet samt utsett ett tjog specialiståklagare. Det skall vara klart att miljöbalkens kapitel om miljöbrott (kapitel 29) är ett av balkens centrala kapitel, med stor betydelse i praktiken.

Samlat kan vi iaktta en målmedveten förstärkning av miljöpolitiken. Man betonar behovet av effektiva åtgärder för att förhindra och förebygga miljöskador. Man betonar samtidigt också att de som trots allt överträder gällande 
bestämmelser skall ställas till ansvar. De som begått ett miljöbrott skall bestraffas. Budskapet är alltså ett krav på en effektivare miljöpolitik, en effektivare miljörätt, och samtidigt en effektivare miljöstraffrätt. Dåvarande justitieministerns Laila Freivalds fastslog i maj 2000 att

“[m]in och regeringens starka betoning av vikten att bekämpa miljöbrotten måste ses i ljuset av vad vi vet om de miljöhot vi står inför och vad de betyder för hela vår existens. Skyddet av miljön och människors hälsa är en av de mest angelägna samhällsuppgifterna. Vår tillgång till ren luft att andas, rent vatten att dricka, hushållandet med naturresurser och energi, bevarandet av den biologiska mångfalden, är alla frågor som berör hela mänsklighetens överlevnad."

På motsvarande sätt har regeringen också vid andra tillfällen uttalat att miljöbrottsbekämpningen skall vara en prioriterad verksamhet för polis och åklagare. Det förebyggande arbetet skall bli effektivare och risken för upptäckt skall öka. Begångna brott skall utredas och lagföras betydligt snabbare och i långt större utsträckning än tidigare. ${ }^{4}$

Miljöbrottsbekämpningen skall således - enligt dessa uttalanden - vara en prioriterad del av den allmänna brottsbekämpningen. Uttalandena ställer krav på en särskild miljöstraffrättspolitik som skall vara effektivare än tidigare. Men samtidigt skall denna miljöstraffrättspolitik vara integrerad med den allmänna brottskontrollen. Vad vi då får är en särskild miljöstraffrättspolitik som är en integrerad - och prioriterad - del av den allmänna straffrättspolitiken, vi får en allmän straffrätt och en allmän straffrättslig kontroll, samt en speciell miljöstraffrätt med en i viss mån specialiserad brottskontroll.

Miljöstraffrätten kan emellertid inte helt frigöras från miljörätten. Miljöstraffrätten kvarstår som miljörättens förlängda - och vid behov hårt slående - arm. Men de ovan citerade uttalandena anger väldigt tydligt att miljöstraffrätten framför allt utgör en del av straffrätten och den straffrättsliga kontrollen. Detta innebär ett paradigmskifte: verksamheten styrs inte längre enbart, eller ens väsentligen, av de miljöpolitiska målsättningarna, utan av de straffrättspolitiska målsättningarna. Miljöstraffrätten är visserligen en specialiserad del av straffrätten, men i grunden gäller de allmänna straffrättsliga grundsatserna och de allmänna principerna för fastställande av straffansvar. Också straffrättens allmänna begränsningar som styrmedel för mänskligt beteende gör sig gällande. Den miljöstraffrättsliga kontrollen utövas huvudsakligen av samma myndigheter, eller samma typ av myndigheter, som utövar brottskontroll i allmänhet. Beslut om straffrättsligt ansvar fattas också i detta fall i sista hand av en allmän domstol, med stöd av ett regelverk som i allt väsentligt svarar mot det som gäller för andra brott. De möjligheter och de medel som står till buds i detta avseende svarar i allt väsentligt mot dem som gäller inom straffrätten i allmänhet.

Miljöstraffrätten kan inte förädlas till en sådan tulipanaros som väsentligt skiljer sig från grundformen, den allmänna straffrätten.

Vad innebär detta i förlängningen? Har vi redan nu, eller skall vi utarbeta, ett 
särskilt miljökriminalpolitiskt program kring en kärna av den existerande miljöstraffrätten? Skall miljöområdet vara en del av det allmänna kriminalpolitiska och straffrättspolitiska programmet? Det skall det förmodligen vara. Det förefaller ju inte särskilt motiverat att ett område som betecknas som en prioriterad del av brottsbekämpningen lämnas utanför de allmänna kriminalpolitiska och straffrättspolitiska programmen.

I detta paradigmskifte från miljöpolitik till straffrättspolitik finns det inbyggt sådant som innebär en risk för motsättningar: Inom miljörätten och miljöpolitiken betonas straffrättens betydelse, men enbart som en förlängning av miljöpolitiken i allmänhet, och då väsentligen på den allmänna miljöpolitikens villkor. Enligt en straffrättslig granskning skall åter miljöstraffrätten framför allt vara straffrätt och inte miljöpolitik. I den kontext som gäller för straffrättslig kontroll i praktiken är miljöstraffrätten därtill en ganska udda företeelse. Ett miljöbrott och dess förövare är trots allt inte den normalform som brottskontrollen främst fokuseras på.

Det är befogat och realistiskt att ifrågasätta vilken konsensus som verkligen finns på miljöbrottsområdet, dvs. om vad som skall göras när det gäller de straffrättsliga insatserna mot miljöbrott och hur dessa insatser skall se ut. En väsentlig orsak till denna osäkerhet är att den miljöstraffrättsliga tillämpningen i många av de i praktiken viktigaste fallen sker utifrån de gränser för tillåten miljöpåverkan som anges i enskilda tillståndsbeslut givna av olika myndigheter. Dessa gränser är inte absoluta. Det finns skillnader i de värderande bedömningarna och i de normativa övervägandena i beslutsförfarandet och dessa smittar av sig på den straffrätt som rör miljöområdet. ${ }^{5}$

\section{Miljöstraffrätten som straffrätt - kriminaliseringsbesluten}

I min fortsatta granskning utgår jag från att miljöstraffrätten är en specialiserad del av straffrätten. Jag antar att miljöstraffrätten erbjuder vissa möjligheter att förstärka den allmänna miljörätten, men att det samtidigt finns vissa grundläggande begränsningar som gäller straffrätten och den straffrättsliga kontrollen i allmänhet som inte får nonchaleras. Jag granskar miljöstraffrätten som straffrätt och inte som miljöpolitik.

Vid en granskning av straffsystemet är det viktigt att göra skillnad mellan olika nivåer. ${ }^{6}$ Vilka nivåer för beslutsfattande finns det, varför skall man på en viss nivå ta vissa beslut eller vidta vissa åtgärder och hur skall detta ske? En sådan analys anger samtidigt vilket syfte olika beslut har, hur besluten skall utformas för att vara rationella och vilka verkningar man i bästa fall kan förvänta sig att uppnå. De tre nivåerna är lagstiftningsnivån, dvs. den nivå där kriminaliseringsbesluten fattas, beslutsnivån, dvs. den nivå som gäller beslut om förundersökning, lagföring och dom med stöd av gällande lagstiftning, samt verkställighetsnivån, dvs. den nivå där domar verkställs. I följande granskning utelämnar jag verkställighetsnivån. Då det gäller verkställighet av domar som avser miljöbrott finns det inte sådana särdrag som kräver en speciell granskning. 
På lagstiftningsnivån fattas de grundläggande kriminaliseringsbesluten. Vilka gärningar skall kriminaliseras och vilka straff skall utsättas för dem? Eller omsatt på miljöområdet: vilka miljöbrott skall finnas och vilket skall det abstrakta straffvärdet för dem vara? Hur allvarliga uppfattas dessa brott således vara $\mathrm{i}$ jämförelse med andra brott.?

Ett beslut att kriminalisera en bestämd gärning måste alltid - för att kriminaliseringsbeslutet skall vara rationellt - kunna motiveras med hänvisning till ett antal goda skäl. ${ }^{8}$ Kriminaliseringen skall vara nödvändig för att skydda ett visst preciserat rättsligt intresse, som är tillräckligt viktigt för att berättiga till att använda straffrättsliga medel. Då det gäller miljöbrotten är detta intresse klart och odiskutabelt: en god miljö är ett centralt villkor för allt liv.

Ett kriminaliseringsbeslut förutsätter också att det är möjligt att med tillräcklig precision på förhand bestämma, att en viss typ av gärning är skadlig eller farlig för det intresse som man vill skydda. Denna typ av gärning skall alltså vara sådan som erfarenhetsmässigt skadar intresset eller utgör en allvarlig risk för att det skadas. Gärningstypen skall emellertid inte bara vara skadlig/farlig för intresset, utan den skall också vara klandervärd. Straffrättens centrala budskap är ju ett institutionaliserat klander. Gärningstypen skall ytterligare vara så väl preciserad och definierad, att det är möjligt att åstadkomma en styrning genom att formulera rättsliga normer av påbuds- eller förbudstyp som gäller gärningen.

Detta krav är i många avseenden problematiskt då det gäller kriminaliseringsbeslut på miljöområdet. Miljöproblemen har ofta en komplex natur och det kan därför vara svårt att fastställa ett tillräckligt starkt kausalförhållande mellan en viss gärningstyp och en miljöskada. Det kan också vara svårt att tillräckligt exakt precisera just en viss typ av gärning som den relevanta. Grundenheten för en straffbestämmelse är en enskild gärning, medan den skadliga miljöpåverkan som man önskar förhindra genom kriminaliseringen ofta är en konsekvens av en kontinuerlig och komplex verksamhet som svårligen kan reduceras till en bestämd gärning. I vissa fall är det också uppenbart att det som man vill förhindra framför allt är ett resultat av en livsstil som bara bristfälligt kan uppdelas i avgränsade konkreta gärningar.'

Ofta är det också starkt ifrågasatt om det handlar om gärningar som verkligen kan klandras. I vissa avseenden - särskilt ur en begränsad ekonomisk synpunkt är ju de miljöskadliga eller miljöfarliga gärningarna ofta både förnuftiga och viktiga eller kanske t.o.m. omöjliga att undvika. Också verksamhet som är miljöförstörande tillåts på grund av att den är nödvändig eller vigtig. Det verkar logiskt att det som är viktigt skall tillåtas och det tillåtna är självklart lovligt. Det som är lovligt kan man heller inte klandra.

Detta är grunden till att man ofta - och med starka skäl - har ifrågasatt om kriminalisering av vissa gärningar på miljöområdet verkligen är ett bättre alternativ än andra tillbudsstående alternativ, t.ex. en miljöstyrning som uteslutande 
bygger på administrativa normer eller som använder sig av olika slag av ekonomiska styrmedel. ${ }^{10}$ Detta är en grundläggande diskussion som jag helt förbigår här, trots att just denna diskussion är central inom miljöpolitiken. Jag tar alltså för givet att det är befogat att kriminalisera vissa gärningar på miljöområdet. Jag accepterar också utan kritisk granskning tesen att man i den gällande miljöstraffrätten på ett tillfredsställande sätt har kunnat ringa in just de gärningar som förtjänar att bli kriminaliserade.

Det betyder också att jag som utgångspunkt accepterar att man vid formuleringen av de enskilda gärningsbekrivningarna som gäller miljöbrott har beaktat de krav och begränsningar som följer av brottmålsförfarandet. Det måste på förhand finns en rimlig sannolikhet för att man i praktiken kan uppfylla de krav som gäller för en fällande dom. En gärningsbeskrivning som förutsätter en så besvärlig bevisning för en fällande dom, att det är högst orealistiskt att man i praktiken uppnår det nödvändiga kravet ställt utom rimligt tvivel är i längden bara kontraproduktiv. I detta avseende tror jag dessvärre att det finns ett antal skenkriminaliseringar som inte har någon faktisk betydelse utanför lagboken.

På kriminaliseringsnivån handlar det framför allt om allmänprevention. Vi är övertygade om att kriminaliseringsbesluten genom sin blotta existens har en beteendestyrande verkan. Också på följande nivå, beslutsnivån, dvs. framför allt domsnivån, har allmänpreventionen en viss betydelse. Men på denna nivå handlar det trots detta primärt om vedergällning. Vi bestraffar någon på grund av att denne inte tog det förbud som uttrycks i kriminaliseringen på allvar, utan begick den straffbelagda gärningen. Domsnivån är repressiv dvs. tillbakablickande. Men i samverkan med besluten på de andra nivåerna ser vi samtidigt här en inbyggd prevention. Genom att brottslingen bestraffas på ett rättvist sätt visar samhället att straffsystemet inte bara ger uttryck ett tomt hot, utan att det är effektivt."

Denna effektivitet är nödvändig av hänsyn till den allmänna laglydnaden. Även om de grundläggande värderingarna och de kriminaliseringar som byggs på dessa värderingar uppfattas som legitima och riktiga av befolkningen, kan ett ineffektivt straffsystem inte skapa eller bevara den tilltro som krävs för att upprätthålla fortsatt allmän laglydnad. Vad som krävs är att allmänheten uppfattar att straffsystemet fungerar både på ett rättssäkert och ett tillräckligt effektivt sätt. ${ }^{12}$ På miljöstraffrättens område innebär detta att både rättvisa och ett effektivt miljöskydd skall främjas.

I bägge dessa avseenden måste vissa förutsättningar bli uppfyllda. Rättvisekravet innebär att det skall finnas en grundläggande acceptans av normernas utformning och deras tillämpning i praktiken. Avgörandena skall utmärkas av rättssäkerhet. En vigtig del av detta är kravet på en rättvis rättegång på ett sådant sätt som detta krav formulerats framför allt i de normer som gäller internationella mänskliga rättigheter. För att uppfylla effektivitetskravets förutsättningar gäller det åter att försäkra sig om, att de faktorer som visat sig vara centrala för 
upprätthållande av allmän laglydnad realiseras. Det betyder att de straffnormer som man skall iaktta är tillräcklig tydliga och också förmedlas tillräckligt tydligt genom de brottskontrollerande myndigheternas beslut. Sannolikheten för att en sanktion följer på en normöverträdelse skall vara tillräckligt stor, samtidigt med att det straff som följer på överträdelsen är tillräckligt strängt. Kort sagt förutsätter effektiviteten tillräcklig normkunskap, tillräckligt stor sanktionssäkerhet vid normbrott och tillräcklig sanktionsstränghet. ${ }^{13}$

Att uppfylla effektivitetskravet är i flera avseenden problematiskt inom den straffrätt som gäller på miljöområdet. Kravet på att uppnå och sprida tillräcklig normkunskap försvåras betydligt av att de centrala straffbestämmelserna inte kan uttryckas i absoluta förbud att skada eller utsätta miljön för fara. ${ }^{14}$ Enligt brottsbeskrivningen för miljöbrott i miljöbalken 29 kap. $1 \S$ bestraffas vissa gärningar bara under förutsättning av att inte behörig myndighet har tillåtit förfarandet eller detta är vedertaget. Även det att gärningen "med hänsyn till omständigheterna anses försvarlig" gör den rättsenlig. Enligt miljöbalken 29 kap. $4 \S$ st 1 bestraffas en gärning som otillåten miljöverksamhet, men bara då vederbörande inte har inhämtat tillåtlighetsbeslut, tillstånd, godkännande eller medgivande eller gjort en anmälan som föreskrivits för detta. Försvårande av miljökontroll enligt miljöbalken 29 kap. $5 \S$ st. 1 förutsätter åter att gärningen sker i strid mot vad som föreskrivs i föreskrifter som har meddelats med stöd av vissa författningar eller beslut.

Gemensamt för alla dessa brottsbeskrivningar är att den väsentligaste delen av beskrivningen inte framgår av straffbestämmelsen, utan förutsätts vara uttryckt i andra kompletterande normer. Dessa normer formuleras på en annan nivå än kriminaliseringsnivån och vid formuleringen av dem har behörig myndighet fått ett betydande utrymme för ändamålsenlighetsprövning. Här har vi mycket klart lämnat området för straffrättsliga beslut och hamnat långt in på näringspolitikens och miljöpolitikens område.

Besluten om vad som tillåts fattas med stöd av mål- och medelorienterade normer som ger utrymme för stor flexibilitet. Vid besluten beaktas faktorer som både är svåra att precisera, utreda och att bevisa, vilket gör att utrymmet för prövning blir relativt stort. Vid prövning av tillstånd förutsätts ofta att tillståndsmyndigheten gör en intressejämförelse där den fördel som en åtgärd innebär avvägs mot de skador, olägenheter och förmånsförluster som åtgärden förorsakar. Ju större ekonomiska förmåner som står på spel - ofta bedömt utgående från ett begränsat lokalt eller nationalt perspektiv - desto större tillåts de negativa konsekvenserna vara. I detta fall tillåter man t.o.m. åtgärder som innebär betydande risker för miljön. Med fog har man konstaterat att den rättsliga handläggning som sker på miljöområdet inte handlar om att sätta spärrar mot risker, utan om att legalisera risker. En laglig risk är rättsligt sett ingen risk, och en tillåten miljöskada är rättsligt sätt inte någon relevant skada. ${ }^{15}$ 
Tillåtlighetsbesluten, tillstånden, godkännandena eller medgivandena på miljöområdet är så som de ofta formuleras i praktiken relativt oprecisa. ${ }^{16}$ Trots detta är de en del av den gärningsbeskrivning som skall tillämpas vid fastställande av straffansvar. Brister i detta avseende står i strid mot legalitetsprincipens krav på precision, och sådana brister kan vara svåra att korrigera på grund av det analogiförbud som gäller vid tolkningen av straffrättsliga normer. På miljöstraffrättens område gäller naturligtvis samma grundläggande krav som på straffrättens område i allmänhet. Den straffrättsliga legalitetsprincipen gäller fullt ut.

I praktiken kan man i flera avseende se en bristande samverkan mellan tillståndsgivande myndigheter och myndigheter inom miljöbrottskontrollen. En sådan brist på samverkan blir mycket besvärande och skadlig för förtroendet för rättssystemet i en situation, då en brottmålsdomstol fastställer straffansvar för ett miljöbrott som gäller en viss verksamhet, ungefär samtidigt som en annan myndighet beviljar ett framtida tillstånd som avser samma verksamhet just i den form som bedömts vara ett brott. ${ }^{17}$ Sådana beslut kan naturligtvis vara fullt rättsenliga och därför juridiskt oklanderliga. Men besluten framstår som motstridiga, och därigenom underminerar de på ett fatalt sätt det som måste vara miljöstraffrättens centrala budskap - att miljöskadlig verksamhet är brottslig.

\section{Fastställande av ansvar för miljöbrott}

Kunskapen om innehållet av en norm förstärks genom en enhetlig och förutsebar praxis. Det skall vara så klart som möjligt på förhand vilka gärningar som bedöms vara brott och föranleda straffansvar och vilka som faller utanför kriminaliseringens ramar.

En kriminalisering av en viss gärning kan ges varierande omfattning beroende på vilka krav på konstaterbar följd som uppställs. Traditionellt har man gjort en skillnad både mellan effektdelikt och beteendedelikt och mellan skadedelikt och olika former av faredelikt. På miljöstraffrättens område har man kunnat iaktta en utveckling från skadedelikt mot faredelikt. ${ }^{18}$ Gärningsbeskrivningarna är därför numera vanligen utformade på ett sådant sätt att det inte krävs att gärningen gett upphov till en konstaterbar skada, utan det räcker med att gärningen gett upphov till fara för skada, varit ägnad att medföra skada, kunnat medföra skada, eller varit av en sådan typ som kan medföra skada. Man skiljer mellan konkret fara, abstrakt fara och presumerad fara. För tre av de centrala brotten i miljöbalken, nämligen miljöbrott (miljöbalken 29 kap. 1 §), vållande till miljöstörning (miljöbalken 29 kap. 2 §) och miljöfarlig kemikaliehantering (miljöbalken 29 kap. $3 \S$ ) är det tillräckligt om det förelegat en abstrakt fara. Det gäller i detta fall bara att bevisa att gärningen typiskt sett medfört en risk för skada och inte att man leder i bevis att en verklig konkret fara har förelegat. ${ }^{19}$ Generellt sett kan man anse att bevisproblemen blir mindre, då man går från skadedelikt till faredelikt, samt då man inom faredelikten går från 
konkreta faredelikt till abstrakta eller presumerade faredelikt. I teorin har det alltså blivit lättare att leda några av de centrala brottsliga gärningarna på miljöområdet $\mathrm{i}$ bevis.

Men också inom miljöstraffrätten ligger bevisbördan primärt hos åklagaren. De krav på en rättvis rättegång som följer bl.a. av artikel 6 i Europeiska människorättskonventionen gäller fullt ut. Dessa rättssäkerhetskrav innebär helt uppenbart vissa svårigheter att uppnå effektivitet, åtminstone om effektivitet mäts i fällande domar. Med hänvisning till sådana effektivitetsproblem har man krävt att ytterligare åtgärder vidtas för att underlätta bevisningen t. ex. genom att införa ett ansvar utan krav på uppsåt eller oaktsamhet, eller en åtminstone $\mathrm{i}$ viss mån omvänd bevisbörda. ${ }^{20}$ Med stöd av vissa avgöranden av Europadomstolen kan man sluta sig till att en rätt långtgående användning av presumtioner inte strider mot Europakonventionen. ${ }^{21}$ Man kan därför väl tänka sig att man också på miljöstraffrättens område tar i bruk presumtioner som innebär att en del av bevisbördan läggs på den anklagade. Sådana presumtioner måste emellertid hållas inom rimliga gränser och alltid ge den anklagade rätt att bevisa presumtionens ohållbarhet.

Att bedöma om en gärning har begåtts med uppsåt medför alltid problem. Detta gäller också på miljöstraffrättens område. Att införa ett objektivt ansvar kan inte försvaras, på grund av att detta innebär att man ger avkall på en av straffsystemets grundläggande principer, skuldprincipen.

Bevissvårigheter då det gäller gränsdragningen mellan uppsåt och oaktsamhet kan väsentligen elimineras genom att vid fastställandet av straffansvar jämställa en uppsåtlig gärning med en oaktsam gärning. På miljöstraffrättens område har detta skett bl.a. i den gärningsbeskrivning som gäller miljöfarlig kemikaliehantering (miljöbalken 29 kap. 3 §) och den som gäller otillåten miljöverksamhet (miljöbalken 29 kap. 4). En betydande skillnad då det gäller straffvärdebedömningen finns däremot då det gäller miljöbrott enligt miljöbalken 29 kap. $1 \S$ å ena sidan och vållande till miljöstörning (miljöbalken 29 kap. 2 §) å andra sidan. Ett miljöbrott som bedöms vara grovt har en straffskala som sträcker sig till fängelse i högst sex år, medan straffet för den oaktsamma varianten aldrig kan bli strängare än fängelse $\mathrm{i}$ högst två år.

Problemen vid uppsåtsbedömningen och vid gränsdragningen mellan uppsåt och oaktsamhet gäller för hela det straffrättsliga området och inte bara inom miljöstraffrätten. Inom miljöstraffrätten förstärks emellertid problemen på grund av att miljöbrott som begås med direkt uppsåt är mycket ovanliga (de förekommer förmodligen bara då det gäller flora- och faunakriminalitet), och på grund av att också brott som begås med indirekt uppsåt är ganska sällsynta. Om uppsåt förekommer handlar det därför vanligen om eventuellt uppsåt. Den gängse uppsåtbedömningen förutsätter i ett sådant fall att det eventuella uppsåtet fastställs med hjälp av det hypotetiska provet. ${ }^{22}$ På miljöområdet, där kausaliteten mellan handlingen eller underlåtelsen att handla och miljöskadan eller faran 
för miljöskadan kan vara svår att överskåda, leder ett sådant hypotetiskt prov sällan till önskad säkerhet. Ett kvalificerat sannolikhetsuppsåt skulle här vara ett mer precist redskap för att fastställa ansvar. ${ }^{23}$ Därtill kan man mycket väl förespråka att en uppsåtlig gärning och en oaktsam gärning jämställs också då det gäller miljöbrott enligt miljöbalken 29 kap. 1 §.

\section{Sanktionssannolikheten}

En effektiv brottsbekämpning förutsätter en tillräckligt stor sanktionssannolikhet. En bristande sanktionssannolikhet har varit ett av de största problemen inom miljöstraffrätten. Flera empiriska undersökningar har visat att sannolikheten för att den som begått ett miljöbrott ställs till ansvar för genom en fällande brottmålsdom är liten, t.o.m. mycket liten. ${ }^{24}$

Mörkertalet uppskattas vara mycket stort på grund av att brotten aldrig kommer till de förundersökande myndigheternas kännedom. Miljöbrotten uppfattas vara "offerlösa" brott i den bemärkelsen att de sällan drabbar ett enskilt identifierbart offer som har ett särskilt intresse av att inkomma med en brottsanmälan. Vissa av brotten förblir också dolda under lång tid på grund av att de effekter som gör att brotten kan uppdagas först inträffar långt efter det att gärningen begåtts. Miljöbrotten har inte hört till de områden som prioriterats högt inom polisens verksamhet - en viss förändring har i detta avseende skett först under de senaste åren. Miljötillsynsmyndigheterna har åter uppfattat att deras roll primärt är en annan än den som består att få folk fällda för miljöbrott. I en enkätundersökning som RÅ genomförde i slutet av 1990-talet uppgav man som vanliga orsaker till att man inte rapporterade miljöbrott att man föredrog att satsa på att avhjälpa felet eller att man prioriterade tillsynsarbetet och kontakten med tillsynsobjektet framför en strikt lagtillämpning. ${ }^{25}$

En konsekvens av allt detta har varit att miljöbrott inte rapporteras eller observeras av relevanta myndigheter på ett effektivt sätt.

Också då det gäller brottsutredning och förundersökning har man kunnat konstatera flera problem. Utredning av miljöbrott är resurskrävande. Sådana utredningar ställer krav på sakkunskap både då det gäller tekniska, naturvetenskapliga och miljövetenskapliga problem och då det gäller rättsliga frågor. Utan tillräckliga resurser och tillräcklig samverkan kan utredningen inte slutföras på ett tillfredsställande sätt eller inom en sådan tid som krävs för att unvika förlust av bevis eller före fastställd preskriptionstid. Också brottmålsrättegångarna blir komplicerade vilken medför att antalet ogillade åtal blir exceptionellt högt.

Jag kunde i detta fall hänvisa till statistiska uppgifter från olika källor och från skilda empiriska undersökningar. ${ }^{26} \mathrm{I}$ dagens läge är sådana uppgifter från 1980talet och 1990-talet dock tämligen ointressanta. Det är nämligen sannolikt att miljöbalken och de organisatoriska förändringar inom framför allt åklagarväsendet, men också inom polisväsendet, har medfört förändringar i utfallet av brottskontrollen. ${ }^{27}$ Sådana förändringar kan emellertid med större säkerhet fastställas 
empiriskt först då en längre tid har förflutit. I dag kan vi inte göra annat en tro och hoppas att en betydande ändring har inträffat i praktiken. Men ännu kan vi inte belägga den med säkerhet. Och det finns några oroande punkter.

Genom den nya miljöbalken ålades tillsynsmyndigheterna en absolut skyldighet att anmäla misstankar om brott mot balken till polismyndighet eller åklagaren. ${ }^{28}$ Denna anmälningsplikt är absolut och frigjord från rätt till egen ändamålsenlighetsprövning. Tillsynsmyndigheten skall inte ta ställning till om den misstänkta överträdelsen skett med uppsåt eller varit en följd av oaktsamhet eller ren våda. Tillsynsmyndigheten skall inte heller bedöma om överträdelsen kan betraktas som ringa.

Denna tillsynsverksamhet och denna anmälningsplikt sker inte alltid på ett tillfredsställande sätt. Miljötillsynen är i stor utsträckning kommunal. Det råder stora skillnader inom den kommunala tillsynen beträffande omfattning och kvalitet mellan olika kommuner. Företag i olika kommuner befinner sig klart i olika situationer och det uppstår en viss typ av olycklig konkurrens mellan kommunerna. Företag kan välja att etablera sig i eller flytta sin verksamhet till kommuner som har lägre miljökrav och mindre strikt tillsyn än andra. Kommuner med låga ambitioner inom miljötillsynen kan locka till sig arbetstillfällen och skattekraft på bekostnad av kommuner med högre ambitioner. Miljön i kommuner med lägre ambitioner ges ett sämre skydd än i andra kommuner. ${ }^{29}$

Stefan Karlmark har i en artikel om miljöbrottsbekämpningen påtalat vissa kommunala politikers uppenbara ovilja att följa lagens bestämmelser och anmäla misstänkta fall av miljöbrott. ${ }^{30}$ Han konstaterar bl.a.:

"I vissa kommuner har politikerna gått mycket hårt åt de tjänstemän som velat iaktta miljöbalkens regler. Sålunda har man i en kommun anställt och avlönat en konsult med uppgift att söka finna fel hos en viss inspektör, varefter konsulten intervjuat verksamhetsutövare om vad de tycker om inspektören, som därefter avskedats. I en annan kommun har man sökt "förbjuda" inspektörerna att ha någon kontakt med polis och åklagare. I en tredje kommun kom det ut $\mathrm{i}$ massmedia att kommunen inte iakttog gällande regler, varefter man från kommunens sida i strid med grundlagen sökte ta reda på vem som upplyst massmedia om det verkliga förhållandet."

Dessa uppgifter bevisar om något att det inte råder konsensus om att miljöbrottsbekämpningen är och skall vara ett prioriterat område.

Då det gäller polisens och åklagarnas aktuella verksamhet och resurser inom miljöbrottslighetens område kan följande nämnas. Vid utgången av mars år 2001 fanns 2.754 balanserade misstankar om miljöbrott. Drygt 2.400 av dessa fanns i balans hos polisen. Anmälningarna om misstänkta miljöbrott har ökat starkt, medan det fortfarande bara är ett fåtal poliser som arbetar med miljöbrott. Polisväsendet problem när det gäller miljöbrott är framför allt en allmän knapphet på resurser och varierande prioriteringar. Prioriteringarna kan leda till att sådana poliser som är väl insatta $\mathrm{i} u$ utredningen av miljöbrott tas i bruk för andra uppgifter. 
Inte heller i detta fall har alltså beteckningen prioriterat område för miljöbrott fătt ett definitivt fotfäste i verkligheten.

På åklagarsidan är situationen betydligt ljusare. Det är uppenbart att åklagarna har fått större resurser än poliserna när det gäller miljöbrottsutredningarna. Antalet åtal och strafföreläggandet har som ovan konstaterats sedan början av år 2000 varit betydligt större än åren innan.

\section{Sanktionssträngheten}

Inte heller det tredje kravet på effektivitet, kravet på tillräcklig sanktionsstränghet, har förverkligats på miljörättens område. Också i detta fall visar flera empiriska undersökningar på en frapperande låg straffnivå. ${ }^{31}$ Det vanliga straffet också för allvarliga miljöbrott har varit böter. Fängelsestraff förekommer nästan aldrig. Under senare tid finns det emellertid en viss tendens att åtminstone bötesstraffen blivit något strängare. ${ }^{32}$ Men fortfarande ligger straffnivån inom miljöstraffrätten på en mycket låg nivå - också om man beaktar andra straffrättsliga påföljder som förverkande, företagsbot och näringsförbud.

Straffskalan för miljöbrott sträcker sig i det grova fallet upp till 6 år fängelse. Det förefaller något märkligt att det konkreta straffvärdet inte av domstolarna uppskattas vara så högt att det berättigar till en fängelsedom. I motsats till vad fallet är då det gäller "artbrott" förefaller det finnas en stark presumtion om att straffet för ett miljöbrott inte skall vara fängelse.

\section{Konklusion}

Vilken blir konklusionen? Har straffrätten sådana förutsättningar som styrmedel inom miljöområdet att det är berättigat att upphöja miljöstraffrätten till ett prioriterat område? Eller är det snarare så att de begränsningar som finns inbyggda $\mathrm{i}$ straffrätten är sådana att de straffrättsliga medlen till och med fungerar dåligt som miljöpolitikens förlängda hand? Hur bidrar straffrätten till att uppställda miljömål kan förverkligas?

Miljöstraffrätten är ett område med vissa inbyggda spänningar. Detta är i viss mån enkelt att förklara. När man på kriminaliseringsnivån formulerar brottsbeskrivningar som avser att skydda miljön sker det i syfte att förebygga framtida miljöskador och risker för miljöskador. Men dessa risker och dessa skador utspringer i allt väsentligt från en källa som samhället på många avseenden önskar skydda, nämligen den ekonomiska produktionen. Skadornas och riskernas uppkomst är direkt anknuten till produktionen av samhällets materiella välfärd. Det finns en källa som i visst avseende är ond, men samma källa är livsviktig för många av de grundläggande ekonomiska funktionerna. Samma ambivalenta inställning kommer till uttryck på det lokala planet i de kommunala politikernas ovilja att följa lag när det kan få ekonomiska konsekvenser.

Lagstiftaren uppfattas vanligen som rationell och oväldig. Denna bild av lagstiftaren har emellertid allt oftare under de senaste decennierna ifrågasatts. 
I politiskt svåra handlingssituationer måste lagstiftaren ofta nöja sig med lösningar som inte är särskilt tillfredsställande. Lagstiftaren kan ställas inför starka politiska handlingskrav i en situation där det är uppenbart att alla berättigade krav inte kan tillfredsställas på samma gång. Då kan resultatet bli en ineffektiv reglering, som ges sken av att vara effektiv och rättvis. Man talar härvid om symbolisk lagstiftning. ${ }^{33}$

Miljöstraffrätten har påståtts vara ett sådant fall av symbolisk lagstiftning. Syftet ställs högt (att skydda miljön), men i verkligheten kan resultatet aldrig bli sådant att syftet realiseras mer än i en mycket ringa grad. Kriminaliseringarna är omfattande, men i verkligheten drabbar kriminaliseringarna bara en mycket begränsad del av brottslingarna och då ofta sådana som begått bagatellbrott eller brott som är mindre allvarliga. De stora brotten är alltför stora för att straffsystemet egentligen skall kunna rå på dem.

Ett problem då det gäller miljöstraffrätten är att vi egentligen vet väldigt lite om hur stor del av skadeverkningarna på miljön som i verkligheten är en konsekvens av brott. Förmodligen är det globalt sett bara en mycket liten del. Straffrätten får då sin största betydelse på betydligt längre sikt, nämligen genom av förverkliga den pedagogiska målsättningen att lära alla att miljön inte får utsättas för skada eller fara för skada. Men också i detta fall är det en nödvändig förutsättning att straffrätten används målmedvetet och konsekvent.

Noter:

1 Se också Council of Europe: Resolution (77) 28 on the contribution of criminal law to the protection of the environment.

${ }^{2}$ Se Nord 1991:2. Forurensning og straff - et nordiskt studium. Se också för Danmarks vidkommande Gorm Toftegaard Nielsen: Milljøstrafferet. Juridisk Institut, november 1996, för Finlands vidkommande Per Ole Träskman: Miljöbrott och kontroll av miljöbrottslighet. Publikationer från institutionen för straff- och processrätt vid Helsingfors universitet A:5. Helsingfors 1992 och för Norges vidkommande Georg Fr. Rieber-Mohn: Miljøkriminalitet - med vekt på krenkelser av det ytre miljø. Juristkontakt 4/89, s 182-188. Motsvarande problem har också framgått i internationella undersökningar. Här kan nämnas det rättsjämförande projekt som under drygt tio års tid genomfördes vid Max-Planck-Institut für ausländisches und internationales Strafrecht i Freiburg im Breisgau ("Umweltschutz durch Strafrecht? National und transnational"). Den nordiska rapporten i detta projekt är redigerad av Karin Cornils och Günter Heine ("Umweltstrafrecht in den nordischen Ländern. Arbeiten zum Umweltrecht 10. Freiburg im Breisgau 1994).

${ }^{3}$ Det finns vissa goda skäl för argumentet att syftet att uppnå en hållbar utveckling också skall beaktas när det gäller tolkningen och tillämpningen av miljöbalkens straffrättsliga bestämmelser. Förutom de sedvanliga straffrättsliga och straffprocessuella tolkningsreglerna, som följer t.ex. av den straffrättsliga legalitetsprincipen, skall man alltså också beakta bestämmelsernas särskilda syfte att uppnå en hållbar utveckling. På grund av legalitetsprincipens styrka, kan syftet att säkra en hållbar utveckling dock inte övertrumfa t.ex. analogiförbudet.

${ }^{4}$ Se Annika Nilsson: Skärpt syn på miljöbrottsligheten, eller ännu en miljöskandal på Hallandsåsen? http://www.jur.lu.se/Lexlundensis.

${ }^{5}$ Se också Carina Pettersson: Reglering och kontroll av miljöstörande verksamhet. Göteborgs universitet. Humanekologiska skrifter nr 19. Göteborg 2001, ("Inledning") s. 18-19.

${ }^{7}$ Träskman, i not 2 a.a., s 3-6

${ }^{8}$ Se Nils Jareborg: Allmän kriminalrätt. Uppsala 2001, s 63-64.

${ }^{9}$ Per Ole Träskman: Miljöbrott och miljöbrottslingar. Oikeus 1994, s123-130. 
${ }^{10}$ Se t.ex. Nils Jareborg: Vilken sorts straffrätt vill vi ha? Dag Victor (red.): Varning för straff. Om vådan av den nyttiga straffrätten. Stockholm 1995, s 34-35.

"Tapio Lappi-Seppälä: Genrela prevention-hypotheses and empirical evidence. Ideologi og Empiri i Kriminologien. Rapport fra NSfKs 37. Forskerseminar. Rusthållargården, Arild, Sverige 1995, s136-159.

${ }^{12}$ Per Ole Träskman: En gemensam europeisk strafflag begränsar nationell kriminalpolitik. 8 reflektioner om kriminalpolitik. BRÅ-rapport 1999:9, s118-139.

${ }^{13}$ Träskman i not 2 a.a., s 9-21 och s 184-189.

${ }^{14}$ Per Ole Träskman: Strafferetligt ansvar for miljofarlig virksomhed. Forhandlingerne på det 32.

Nordiske Juristmode i Reykjavik den 22.-24 august 1990. Del II, s 428-437. Reykjavik 1993.

${ }^{15}$ Kimmo Nuotio: Kan straffrätten användas för miljöskydd? Retfærd 1991, s 3-19.

${ }^{16}$ Stefan Karlmark: Miljörätt ur straffrättsligt perspektiv. Andra upplagan. Stockholm 1999, s 137-145.

${ }^{17}$ Carina Pettersson i not 5 a.a., artikel V ("Rättsliga dimensioner och normativa implikationer vid straffrättslig tillämpning i miljömål”), s 9 .

${ }^{18}$ Träskman i not 2 a.a., s 82-88.

${ }^{19}$ Karlmark i not 16 a.a., s 63-65

${ }^{20}$ Carina Pettersson: Miljödriven utveckling - på gott och ont? BRÅ-Rapport 2001:17.

${ }^{21}$ Hans Danelius: Mänskliga rättigheter i europeisk praxis. En kommentar till Europakonventionen om de mänskliga rättigheterna. Stockholm 2000, s 203-204.

${ }^{22}$ SOU 1996:185. Straffansvarets gränser. Betänkande av straffansvarsutredningen. Del I. Överväganden och förslag, s 81-146 och Del II. Bilagor, s13-102.

${ }^{23}$ Det kan nämnas att Hovrätten över Skåne och Blekinge i en dom nyligen uttryckligen har tagit ställning för att det eventuella uppsåtet med hypotetiskt prov skall ersättas med en form av sannolikhetsuppsåt. "Vid uppsåtsbedömningen i förevarande fall kan konstateras att tt, trots sin berusning, måste ha insett att en alldeles övervägande sannolikhet förelåg för att NJ skulle komma att bli mycket allvarligt skadad genom tts sätt att föra bilen. Även en gärning som företas under sådana omständigheter bör enligt hovrättens mening betecknas som uppsåtlig. Detta hänger samman med att det i praktiken knappast finns skäl att i klandervärdhet skilja mellen en gärning där man har full visshet om konsekvenserna av ens handlande (indirekt uppsåt) och en gärning, som den förevarande, där man inte har full insikt men ändå, med hänsyn till den höga sannolikheten, antar att dessa konsekvenser inträffar." Hovrätten över Skåne och Blekinge, Avd. 2, rotel 21, Dom DB 2208 (2001-12-03).

${ }^{24}$ Se t.ex. Nord 1991:2 , samt de andra källor som anförs i not 2. Se också Inger Eriksson: Miljöbrottslighet - en dold brottslighet, i Brottsutvecklingen 1985. BRÅ-Rapport 1985:5.

${ }^{25}$ Riksåklagaren (1998). Effektivare miljöbrottsbekämpning. Rapport från Riksåklagaren, december 1998.

${ }^{26}$ Under 1990-talet anmäldes enligt den officiella statistikken årligen cirka 300 - 500 brott mot miljöskyddslagen. I genomsnitt ledde cirka 50 av anmälningarna till åtal (inklusive beslut om strafföreläggande). Detta innebär att cirka 1 anmälan på 10 ledde till åtal. Antalet fällande domar var betydligt lägre. Cirka halvdelen av åtalen (inklusive strafföreläggande) ledde till en fällande dom.

${ }^{27}$ Sedan miljöbalken trädde i kraft har antalet brottsanmälningar ökat betydligt. Under år 2000 inkom över 3000 brottsmisstankar till de brottskontrollerande myndigheterna (polis och åklagare), och under perioden januari - juni 2001 tog åklagarna sammanlagt beslut i över 1100 fall gällande misstänkt miljöbrott (Riksåklagarens statistik)

${ }^{28}$ Miljöbalken 26 kap. 2 §.

${ }^{29}$ Fredrik Nilsson: Effektivare mijöbrottsbekämpning? Examensarbete vid Lunds universitet VT-01.

${ }^{30}$ Stefan Karlmark: Miljöbrottsbekämpning - problem, tendenser och mål.

${ }^{31}$ Se i not 2 anförda källor.

${ }^{32}$ Se Nilsson i not 29 a.a., s $95-99$.

${ }^{33}$ Se Nuotio i not 25 a.a.

Adress: Lunds universitet

Box 207

SE - 22100 Lund 